\title{
Report of Trigoniophthalmus alternatus (Silvestri, 1904) (Insecta: Microcoryphia: Machilidae) in Southern West Virginia, USA
}

\author{
Grant D. De Jong \\ GEI Consultants, Inc. 4601 DTC Boulevard, Suite 900. 80237. Denver, Colorado, (CO), USA \\ E-mail: gdejong@geiconsultants.com
}

\begin{abstract}
The introduced jumping bristletail, Trigoniophthalmus alternatus (Silvestri, 1904), is reported from the state of West Virginia, USA, for the first time. This location extends the range of this species $380 \mathrm{~km}$ southwest of its nearest previously reported locality.
\end{abstract}

The machilid jumping bristletail Trigoniophthalmus alternatus (Silvestri, 1904) is widely distributed throughout southern and central Europe and was apparently introduced to northeastern North America, possibly via ballast, sometime prior to 1911, when it was reported from Long Island, New York (Silvestri 1911; Wygodzinsky and Schmidt 1980). Wygodzinsky and Schmidt (1980) reported collection localities for hundreds of specimens of T. alternatus across the northeastern United States from New York and Connecticut south through Pennsylvania and New Jersey to Plummer's Island in the Potomac River on the border between Maryland and Virginia. This species has not previously been reported from the state of West Virginia.

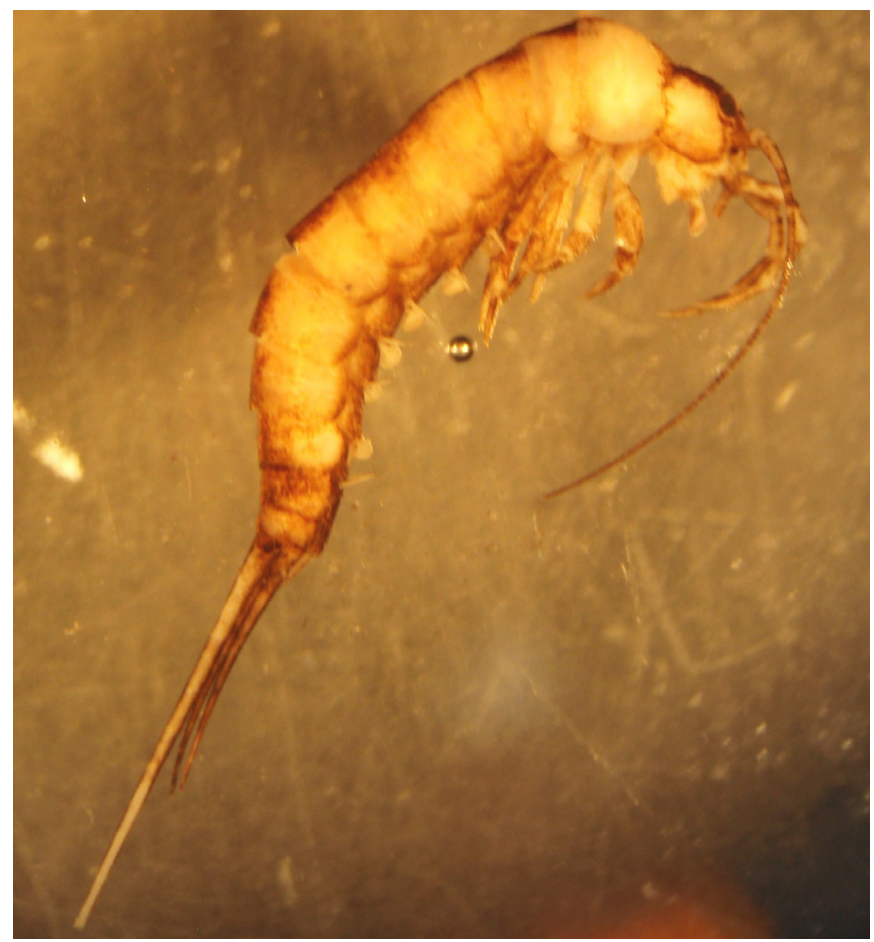

FIGURE 1. Adult of Trigoniophthalmus alternatus from Kanawha County, West Virginia, USA.
During an aquatic biological survey, an adult female of T. alternatus (Figures 1 and 2) was collected on the banks of Cabin Creek near Leewood, Kanawha County, West Virginia, on 12 September 2011. The specimen is publicly available as a voucher specimen in the ecological voucher collection of GEI Consultants, Inc. Geographic coordinates for the collection site are $38^{\circ} 03^{\prime} 24^{\prime \prime} \mathrm{N}, 81^{\circ} 26^{\prime} 33^{\prime \prime} \mathrm{W}$. This location is $380 \mathrm{~km}$ southwest of the nearest previously reported locality for T. alternatus on Plummer's Island. This report represents a new state record for West Virginia and a southwestern extension of the known range of this introduced species in North America.

Although the collection of a single specimen often does not indicate establishment of a species in a new locality, this distinctive species is flightless and the known North American populations are allegedly parthenogenetic (Wygodzinsky and Schmidt 1980). This combination of traits suggests that a permanent population of this species probably occurs in this region of West Virginia.

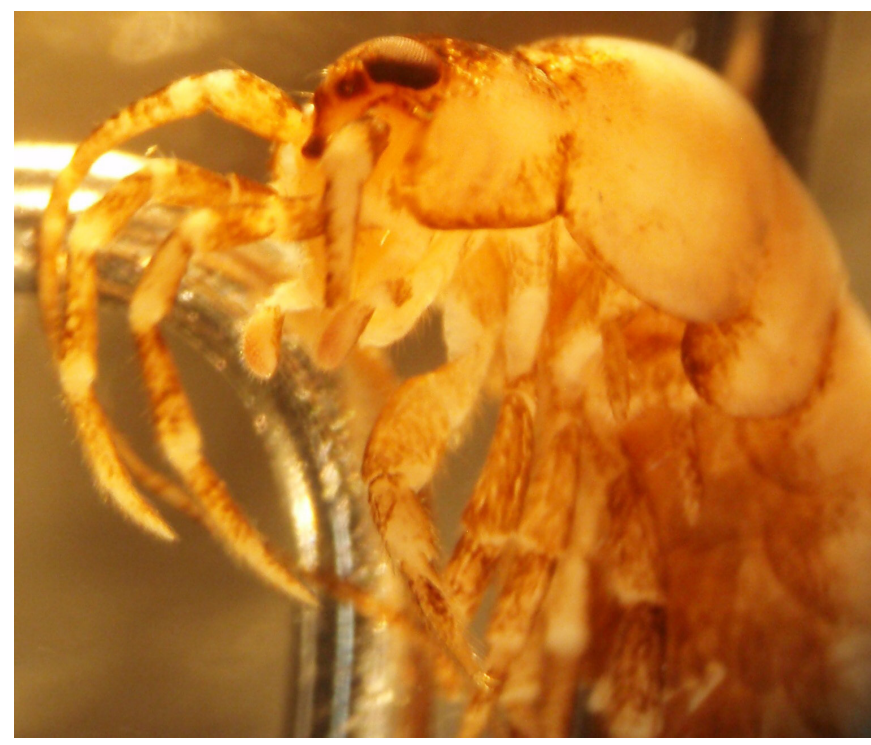

FIGURE 2. Head and thorax of Trigoniophthalmus alternatus from Kanawha County, West Virginia, USA. 
ACKNOWLEDGMENTS: Thanks to the rest of the survey crew and Patriot Coal Corporation for their support. Steve Canton and an anonymous reviewer provided comments on the manuscript.

\section{LITERATURE CITED}

Silvestri, F. 1904. Nuovi generi e specie di Machilidae. Redia 2: 1-9.

Silvestri, F. 1911. Contributo alla conoscienza dei Machilidae dell'America settentrionale. Bollettino del Laboratorio di Zoologia Generale e Agraria della R. Scuola Superiore d'Agricoltura in Portici 5: 324-350.

Wygodzinsky, P. and K. Schmidt. 1980. Survey of the Microcoryphia (Insecta) of the northeastern United States and adjacent provinces of Canada. American Museum Novitates 2701: 1-17.
RECEIVED: November 2012

ACCEPTED: February 2013

Published online: May 2013

EDITORIAL RESPONSIBILITY: Matthew Smart 